\title{
Simulated rainfall following the preplant application of 2,4-D and dicamba in soybean ${ }^{1}$
}

\author{
Diecson Ruy Orsolin da Silva², Marina Luiza Cuchi², \\ Álvaro André Alba da Silva², Bruna Dal'Pizol Novello², Claudir José Basso ${ }^{2}$
}

\begin{abstract}
Soil residues following the application of 2,4-D and dicamba for weed control may delay the establishment and initial development of soybean, but rainfall can reduce the interval required between application and sowing. Rainfall volumes $(0 ; 10 ; 30 ; 60$; and $90 \mathrm{~mm})$ were simulated following the application of 2,4-D (300 and $600 \mathrm{~g}$ a.e. ha $\left.{ }^{-1}\right)$ and dicamba (120 and $240 \mathrm{~g}$ a.e. $\mathrm{ha}^{-1}$ ), and the effects on soybean were evaluated. The application of 2,4-D did not affect the soybean establishment or initial development, regardless of the simulated rainfall volume. However, the dicamba residual reduced the soybean establishment for the lower rainfall volumes. Phytotoxicity was more severe for the highest dicamba rate (75-100\%), being $50-100 \%$ for the lowest rate. The higher volumes of simulated rainfall reduced the phytotoxicity of dicamba in soybean, but were not sufficient to reduce the deleterious effects on the initial development of the crop.
\end{abstract}

KEYWORDS: Glycine max, synthetic auxin, herbicide dissipation.

\section{INTRODUCTION}

In order to manage glyphosate-resistant broadleaf weeds in soybean, one of the most efficient and usual strategies employed by producers is the preplant application of synthetic auxin in tank mixes or the sequential application with others herbicides. Applications of 2,4-D plus residual herbicides have been efficient to control Conyza spp. (Oliveira Neto et al. 2013). The recent registration of dicamba for preplant applications in soybean, in Brazil, offers the producer another option for the management of troublesome weeds.

Dicamba and 2,4-D are commonly tankmixed with glyphosate in preplant soybean, and

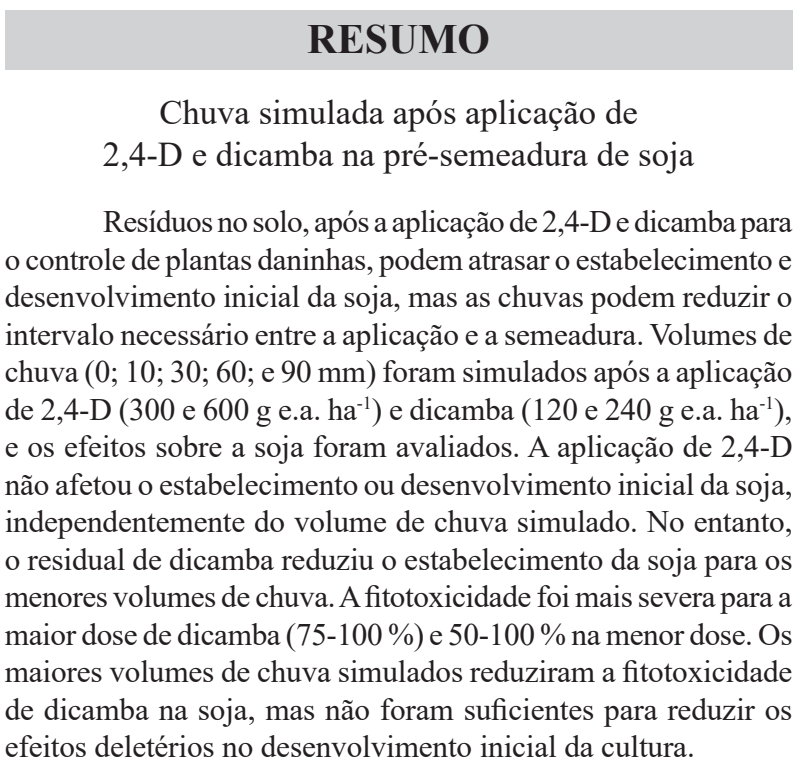

PALAVRAS-CHAVE: Glycine max, auxina sintética, dissipação de herbicida.

provide an excellent control of glyphosate-resistant or tolerant weeds, such as Conyza spp., Richardia brasiliensis, Commelina benghalensis and Ipomoea nil with up to 12 leaves (Osipe et al. 2017). However, these herbicides are considered post-emergent, and preplant applications are restricted to a certain interval before the soybean planting.

The persistence of 2,4-D and dicamba in the soil is influenced by several edaphoclimatic characteristics. Soil texture, $\mathrm{pH}$ and organic matter are the main factors that control the soil adsorption of 2,4-D and dicamba and, consequently, their persistence in the soil (Kah et al. 2007). The degradation of these herbicides is also influenced by microbial activity and soil temperature (Comfort et al. 1992).

\footnotetext{
${ }^{1}$ Received: Apr. 01, 2020. Accepted: June 17, 2020. Published: Sep. 28, 2020. DOI: 10.1590/1983-40632020v5062780.

${ }^{2}$ Universidade Federal de Santa Maria, Campus Frederico Westphalen, Departamento de Ciências Agronômicas e

Ambientais, Frederico Westphalen, RS, Brasil.E-mail/ORCID: diecsonros@hotmail.com/0000-0002-0354-7744, marinaluizacuchi@hotmail.com/0000-0002-3651-4025, alvaroalba1@outlook.com/0000-0002-3854-1449, brunadalpizoln@outlook.com/0000-0003-4283-4399, claudirbasso@gmail.com/0000-0002-3013-5702.
} 
Silva et al. (2011) observed that 2,4-D (502 g a.e. ha $^{-1}$ ) applied at 3 days before planting in a clayey soil did not affect soybean, whereas, in sandy soils, soybean planting must be delayed for at least 21 days. However, there has been no research under Brazilian environmental conditions documenting the effects of soil residues from dicamba on soybean. Soybean is more sensitive to drifting and soil residues from dicamba than from 2,4-D (Thompson et al. 2007, Robinson et al. 2013). No detrimental effects were observed on soybean or cotton from dicamba and 2,4-D applied at one week of preplant, when at least $16 \mathrm{~mm}$ of rainfall occurred between application and planting (York et al. 2004, Thompson et al. 2007). Thereby, rainfall could be an important factor in the dissipation of auxin herbicides from the soil, and it could help to define the application interval required prior to soybean planting.

In Brazil, the interval required between the application of 2,4-D and dicamba and the soybean planting varies according to the rate used, being at least 7 days for 2,4-D and 30 days for dicamba (Adapar 2017a, Adapar 2017b). However, the labels for these herbicides do not specify a minimum rainfall requirement between the herbicide application and soybean planting. In the USA, dicamba (dimethylamine salt) requires a safe preplant interval of 30-45 days, depending on the rainfall volume after the herbicide application (EPA 2012). For the diglycolamine salt of dicamba, the safe preplant interval is 28 days after a minimum rainfall volume of $25 \mathrm{~mm}$ (EPA 2017).

The preplant application of auxin herbicides requires a minimum interval before planting susceptible crops; however, if rainfall precedes planting, it is possible to reduce this interval (Prostko et al. 2003, York et al. 2004, Thompson et al. 2007, Sperry et al. 2017). Thus, high rainfall volumes after the preplant application of 2,4-D and dicamba in soybean could reduce the deleterious effects of these herbicides on the soybean emergence and initial development. Therefore, this study aimed to evaluate the effect of simulated rainfall on the dissipation of auxin herbicides from the soil, in order to avoid detrimental effects on the soybean initial establishment and development.

\section{MATERIAL AND METHODS}

A greenhouse experiment was conducted at the Universidade Federal de Santa Maria, in Frederico
Westphalen, Rio Grande do Sul state, Brazil, during March and April 2019. The used soil (0-25 cm) was collected from a non-agricultural area, and was air dried and sieved. The experimental units consisted of plastic pots with capacity of $8 \mathrm{~L}$ (Ø: $22 \mathrm{~cm} ; \mathrm{h}: 25 \mathrm{~cm})$ filled with soil. The soil type was a Dystrophic Red Latosol (Oxisol), with the following properties: $58 \%$ of clay; $13 \%$ of sand; $29 \%$ of silt; $\mathrm{pH}$ of 5.5 ; and organic matter of $1.4 \%$.

The experimental design was completely randomized, with four replicates. The experimental arrangement was a tri-factorial scheme with an additional control $(2 \times 2 \times 5)+1$. The herbicide 2,4-D (dimethylamine salt) was applied at 300 and $600 \mathrm{~g}$ a.e. $\mathrm{ha}^{-1}$, and dicamba (diglycolamina salt) at 120 and $240 \mathrm{~g}$ a.e. $\mathrm{ha}^{-1}$, at seven days before the soybean planting. Simulated rainfall volumes of 0 ; 10; 30; 60; and $90 \mathrm{~mm}$, in a single event, were applied within 24 hours after spraying the herbicides. A non-treated control was included. The herbicide rates represented 30 and $60 \%$ for the recommended rate of 2,4-D (1,005 g a.e. ha $\left.{ }^{-1}\right)$, and 25 and $50 \%$ for dicamba (480 g e.a. ha-1), and were chosen to simulate the soil dissipation over time, with respect to an estimated half-life in the soil of 5-59 days for 2,4-D and 1.4-11 days for dicamba (Kah et al. 2007).

The herbicides were applied with a $\mathrm{CO}_{2}-$ pressurized backpack sprayer outfitted with a spray boom with two 11002 nozzles spaced $50 \mathrm{~cm}$ apart, calibrated to deliver $150 \mathrm{~L} \mathrm{ha}^{-1}$. The air temperature and relative humidity during the herbicide application were $25^{\circ} \mathrm{C}$ and $78 \%$, respectively. The rainfall simulator was the model developed by Spohr et al. (2015). The simulated rainfall was applied with an oscillating nozzle type Veejet 80100 (Spraying Systems Company), which was placed $2.5 \mathrm{~m}$ above the plastic pots. The pressure was $40 \mathrm{kPa}$, which delivered a rainfall intensity of $155 \mathrm{~mm} \mathrm{~h}^{-1}$. A shade screen was positioned over the plastic pots, in order to avoid soil seal formation induced by the impact of rainfall drops.

The bioindicator plant (soybean - BMX Delta IPRO) was planted at seven days after the herbicide application, at the rate of 21 seeds pot $^{-1}(2.5 \mathrm{~cm}$ depth). Three irrigation events (44 $\mathrm{mm}$ in total) were performed between the soybean planting and emergence, followed by eight events $(60 \mathrm{~mm}$ in total) after the soybean emergence.

The soybean emergence speed index and emergence percentage were evaluated at eight 
days after the beginning of the emergence (DAE). Thereafter, the seedlings were thinned out to four seedlings per pot and the seedling dry matter was determined drying them in an oven at $60{ }^{\circ} \mathrm{C}$, for 72 hours. Soybean phytotoxicity was visually estimated on a scale ranging from 0 to $100 \%$, at 15 and $25 \mathrm{DAE}$ (Robinson et al. 2013). At the end of the experiment (25 DAE), the total dry matter was determined, as previously described.

The data were tested for normality and homogeneity of variance before conducting the Anova. Residual standardized versus leverage dispersion charts were constructed to identify and remove outliers. After that, the data were subjected to the Anova $(\mathrm{F}<0.05)$, in a three-factorial model, with an additional untreated control treatment. When observed interaction for the main effect of the herbicide factor, the herbicide rates and simulated rainfall interaction were analyzed separately by herbicide. For the simulated rainfall factor, when differences were significant, they were analyzed by non-linear regressions. Finally, the Dunnett test $(\mathrm{p}<0.05)$ was used to compare the simulated rainfall treatments with the untreated control.

\section{RESULTS AND DISCUSSION}

There was an herbicide factor effect; thus, the data interaction from herbicide rates and simulated rainfall are presented separately by herbicide. There were no interaction effects between the rate of 2,4-D applied at seven days prior to planting and simulated rainfall for the establishment and initial development of the soybean, in terms of emergence, emergence speed index and dry matter (Figures 1 and 2). There was a simulated rainfall effect for the soybean dry matter. The polynomial model indicated a lower accumulation of dry matter with $54 \mathrm{~mm}$ of rainfall, similarly to the untreated control (Figure 2C). It is important to note that the irrigation conditions after the soybean planting presumably favored a maximum herbicide dissipation, since 2,4-D is easily degraded via hydrolysis and oxidation in wet conditions (Cessna et al. 2017).

The preplant application of 2,4-D at any rate had no adverse effects on the soybean phytotoxicity, regardless of the amount of simulated rainfall (Figures 2A and 2B). These results confirm the information about intervals between the herbicide application and soybean planting included on the labels of 2,4-D products (Adapar 2017b). Likewise, several reports in the literature document the minimal effects of 2,4-D applied at preplanting in susceptible crops (Prostko et al. 2003, York et al. 2004, Thompson et al. 2007, Silva et al. 2011, Oliveira et al. 2015, Sperry et al. 2017). In addition, the soybean dry matter accumulation was higher than in the untreated control (Figure 2C), a fact that may be explained by the occurrence of hormesis (Silva et al. 2019).

The results found in this study cannot be extrapolated to all environmental conditions, because applications of 2,4-D in sandy soils require a longer interval to soybean planting (Oliveira et al. 2015). The half-life of 2,4-D has been reported to vary
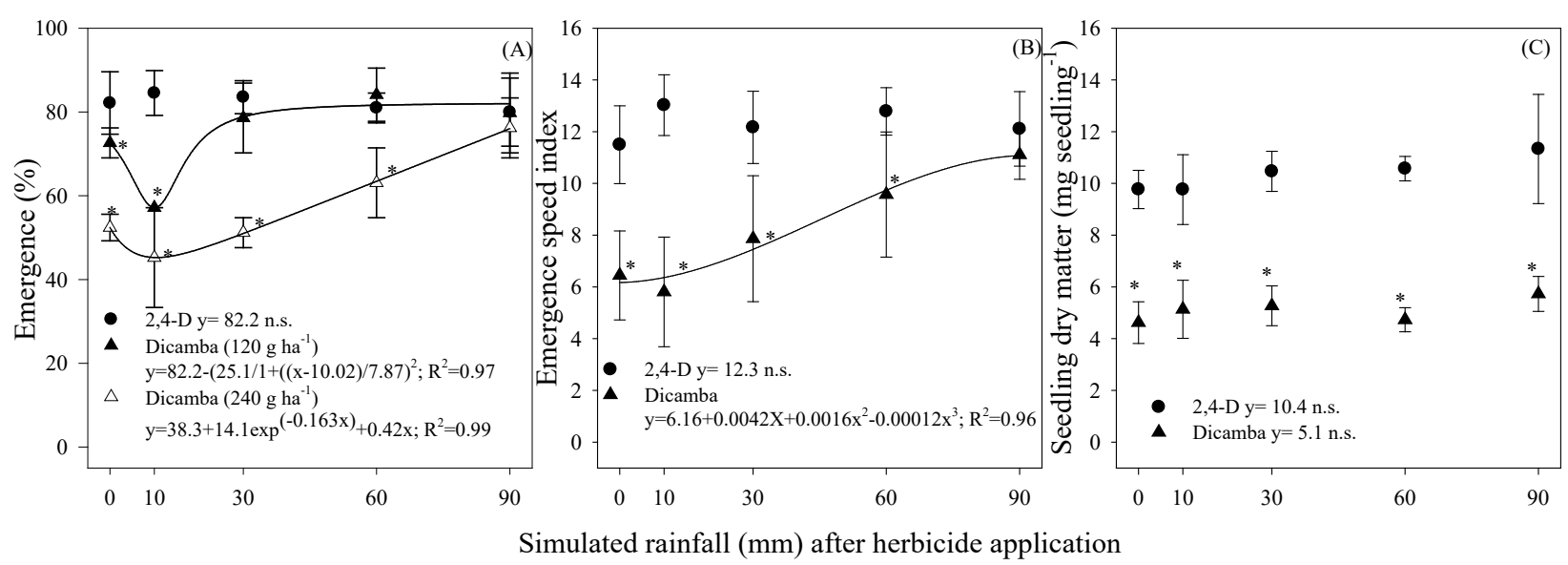

Figure 1. Soybean emergence (A), emergence speed index (B) and seedling dry matter (C), according to simulated rainfall, one day after the application of preplant auxin herbicides in a clayey soil. Bars represent the standard deviation. * Means differ from the untreated control, according to the Dunnett test $(\mathrm{p}<0.05)$. 


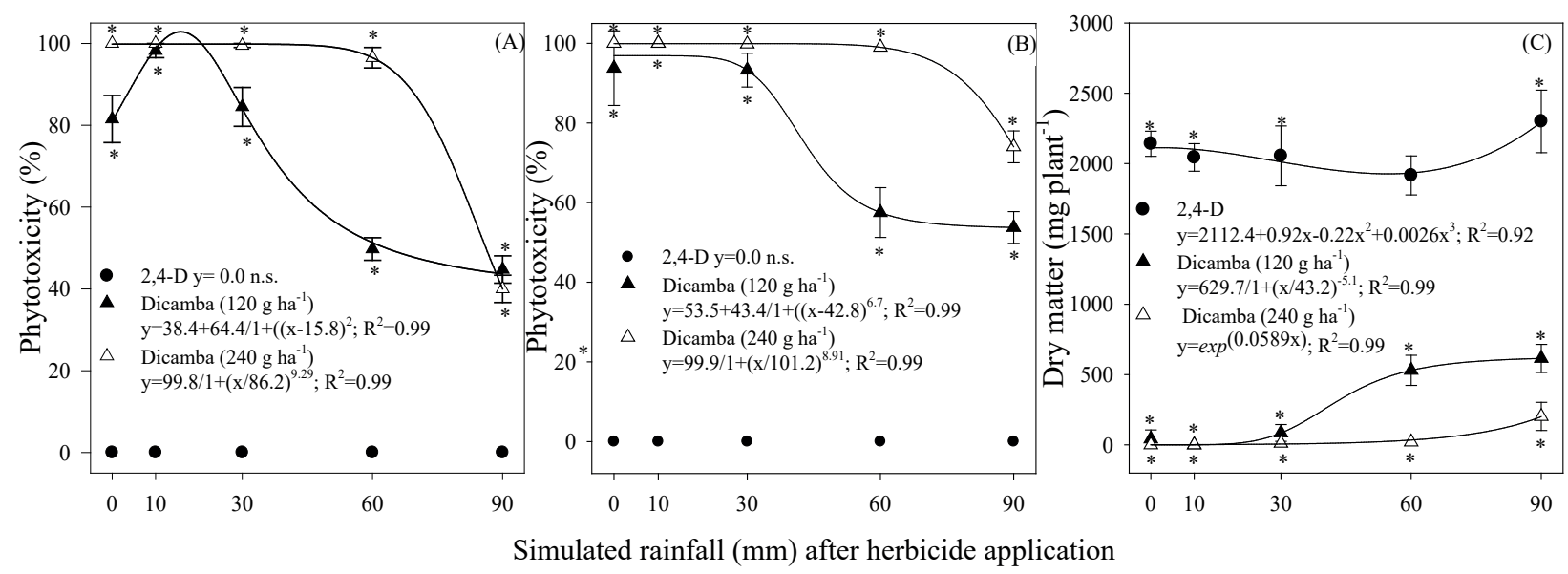

Figure 2. Soybean phytotoxicity at 15 (A) and 25 days after the emergence (B) and dry matter (C), according to the rainfall volume, at one day after the application of preplant auxin herbicides in a clayey soil. Bars represent the standard deviation. * Means differ from the untreated control, according to the Dunnett test $(\mathrm{p}<0.05)$.

between 5 and 59 days, and several factors, such as soil $\mathrm{pH}$, clay content, organic matter and rainfall, influence the dissipation rates of herbicides, changing their persistence in the environment (Kah et al. 2007, Thompson et al. 2007).

The occurrence of rainfall may facilitate the herbicide dissipation, reducing the interval required between the 2,4-D application and the soybean planting. In addition, in a no-tillage soybean system, the residues from previous crops may intercept herbicides, and effectively reduce the concentration that reaches the soil. There is little information in the literature about the influence of rainfall on the dissipation of auxin herbicides before the soybean planting. In one of these studies, Thompson et al. (2007) found that the soybean did not show any deleterious symptoms when 2,4-D was applied at planting, followed by rainfall of $51 \mathrm{~mm}$ over one week; however, when there was only $30 \mathrm{~mm}$, the phytotoxicity was $18 \%$.

The soil residue of dicamba has more severe detrimental effects on soybean than 2,4-D, what may be related to the slow dissipation of dicamba in the environment (Kah et al. 2007), whereas the 2,4-D dissipation occurs easily via hydrolysis and oxidation in wet conditions (Cessna et al. 2017). Similar observations have been made for soybean, cotton and sesame (Prostko et al. 2003, Thompson et al. 2007, Sperry et al. 2017).

There was interaction between the dicamba rates and simulated rainfall for the soybean emergence and total dry matter (Figures 1A and 2C). For the emergence speed index, only the simulated rainfall had a significant effect; and the seedling dry matter was not affected by any of the tested factors (Figures 1B and 1C). Both the adjusted Lorentzian and exponential models, which represent the response of the seedling emergence to the dicamba rates and simulated rainfall interaction, indicate a lower emergence at $10 \mathrm{~mm}$ of simulated rainfall, after the application for both dicamba rates. The soybean emergence increased after this rainfall volume and the deleterious effects were not observed from $30 \mathrm{~mm}$, for $120 \mathrm{~g}$ a.e. ha ${ }^{-1}$. At $240 \mathrm{~g}$ a.e. ha ${ }^{-1}$ of dicamba, the soybean emergence had a linear increase after $10 \mathrm{~mm}$, but the deleterious effects were sustained up to $60 \mathrm{~mm}$ of rainfall, when compared with the untreated control. At $90 \mathrm{~mm}$ of rainfall, the soybean emergence did not differ between the rates of dicamba and 2,4-D and the untreated control. The soybean emergence did not exhibit differences between the residues of 2,4-D and 120 g a.e. ha- $\mathrm{h}^{-1}$ of dicamba, regardless of rainfall, except at $10 \mathrm{~mm}$. Among the dicamba rates, the emergence was higher at $120 \mathrm{~g}$ a.e. $\mathrm{ha}^{-1}$, at $0 ; 30$; and $60 \mathrm{~mm}$, than at $240 \mathrm{~g}$ a.e. ha ${ }^{-1}$.

The logistic model describes an increase in the emergence speed up to $90 \mathrm{~mm}$ of simulated rainfall in soil treated with dicamba, but the index was lower, in relation to the untreated control, with simulated rainfall up to $60 \mathrm{~mm}$ (Figure 1B). The soybean emergence speed is similar between the residues from 2,4-D and dicamba at $60 \mathrm{~mm}$ or more of rainfall. Dicamba caused significant damages in the seedlings dry matter, when compared to 2,4-D and 
the untreated control, even after a simulated rainfall of $90 \mathrm{~mm}$ (Figure 1C). The delay in the soybean establishment due to soil residues of dicamba causes yield losses in susceptible crops, as well as affects the weed management (York et al. 2004).

An interaction between the dicamba rates and simulated rainfall was noted for soybean phytotoxicity at 15 and 25 DAE (Figures $2 \mathrm{~A}$ and 2B). Soil residues of dicamba caused severe levels of soybean phytotoxicity, which increased as the evaluation progressed, for any dicamba rate. At 15 DAE, the Lorentzian model indicated the highest phytotoxicity at $15.8 \mathrm{~mm}$ of simulated rainfall following the application of $120 \mathrm{~g}$ a.e. $\mathrm{ha}^{-1}$ of dicamba; and this was reduced to $45 \%$ after the largest rainfall volume tested. The data for phytotoxicity caused by $240 \mathrm{~g}$ a.e. $\mathrm{ha}^{-1}$ of dicamba were fitted to the logistic model that describes a high phytotoxicity $(99.8 \%)$ up to $45 \mathrm{~mm}$ of rainfall, with a subsequent decline up to $40 \%$, with the highest rain volume tested. A similar phytotoxicity was observed between the dicamba rates, when 10 or $90 \mathrm{~mm}$ were simulated. At $25 \mathrm{DAE}$, the data for soybean phytotoxicity were fitted to the logistic model for both dicamba rates. This model estimates a reduction on the soybean phytotoxicity from 22 and $55 \mathrm{~mm}$ of rainfall to 120 and $240 \mathrm{~g}$ a.e. $\mathrm{ha}^{-1}$, respectively; being, at $90 \mathrm{~mm}$, $54 \%$ for $120 \mathrm{~g}$ a.e. ha $\mathrm{h}^{-1}$ and $74 \%$ for $240 \mathrm{~g}$ a.e. $\mathrm{ha}^{-1}$.

The phytotoxicity from the soil residues of $120 \mathrm{~g}$ a.e. ha ${ }^{-1}$ of dicamba were lower than for $240 \mathrm{~g}$ a.e. $\mathrm{ha}^{-1}$ at $30 \mathrm{~mm}$ or more of simulated rainfall. Similarly, previous studies conducted in the field and laboratory reported a reduction in the symptoms of synthetic auxin from soil residues with an increased rainfall prior to the crop planting (Friesen 1965, York et al. 2004, Thompson et al. 2007). Based on the GUS estimate, 2,4-D and dicamba can be leached from the soil profile, with dicamba having a greater leaching potential than 2,4-D (Inoue et al. 2003). Additionally, in the present experiment, the used soil was collected from the profile of a non-agricultural area, which showed a low organic matter (1.4\%), and possibly the low microbial activity resulted in a persistence of dicamba in the soil. Kah et al. (2007) reported that the dicamba degradation may be slower in soil with organic matter and microbiological activity restriction (Kah et al. 2007).

The soybean emergence and phytotoxicity at 15 DAE were more adversely affected by the dicamba application at $120 \mathrm{~g}$ a.e. ha ${ }^{-1}$, followed by a lower simulated amount of rainfall, when compared to the other rainfall treatments (Figures 1A and 2A). This may be associated with the mobility of dicamba in the soybean germination or root zone. However, this effect was not maintained at $25 \mathrm{DAE}$ (Figures 2B and 2C). A previous study found that the largest amounts of dicamba were concentrated at the depths of 3.8-11.4 cm in soil columns, after $25 \mathrm{~mm}$ of rainfall (Friesen 1965). Furthermore, the dicamba rates had no effect on the pattern of movement in the soil, thus supporting the results found for the soybean emergence (Figure 1A).

The irrigation supplied after planting $(104 \mathrm{~mm})$ did not allow the soybean to recover from the dicamba injury, since the dry matter was drastically reduced by at least $63 \%$ and $88 \%$, for 120 and $240 \mathrm{~g}$ a.e. ha ${ }^{-1}$ of dicamba at $90 \mathrm{~mm}$ of rainfall, respectively, if compared to the untreated control (Figure 2C). Although researchers have attributed the reduction of injuries from synthetic auxins in the soil to rainfall patterns (York et al. 2004, Thompson et al. 2007), it is important to point out that the rainfall accumulating in the interval between the herbicides application and crop planting is more significant than that during the seedling establishment.

Previous reports indicate that the plants recovered from injuries due to synthetic auxin soil residues in late growth stages (York et al. 2004, Zimmer et al. 2019). However, our data conflict with this, as we observed a severe and increasing soybean phytotoxicity between 15 and 25 DAE. This high soybean phytotoxicity could be due to the higher temperatures in the greenhouse than in the field, which could increase the transpiration rates and herbicide absorption from the soil (Zimmer et al. 2019). Similarly, Thompson et al. (2007) evaluated the potential soybean injury from residual auxin herbicide during two years, and found a greater phytotoxicity from dicamba, when the soybean grew in warm temperatures during 5 weeks.

The residual effects of 2,4-D and dicamba depend on a series of factors related to the herbicides (rate and formulation), soil characteristics (organic matter, clay, $\mathrm{pH}$ and microbial activity), temperature and especially the occurrence of accumulated rainfall in the interval between the herbicide application and the soybean planting. The persistence of 2,4-D and dicamba in the soil is dependent on conditions of the site and year, before and after planting (Prostko et al. 2003, York et al. 2004, Thompson et al. 2007). 
The obtained results confirmed the recommendation on the labels of registered auxin products that the application of 2,4-D (300 or $600 \mathrm{~g}$ a.e. $\mathrm{ha}^{-1}$ ) must take place at a minimum of 7 days before the soybean planting, without specifying a minimum rainfall volume in the interval (Adapar 2017b). Dicamba applications at rates of up to $288 \mathrm{~g}$ a.e. ha ${ }^{-1}$ require a minimum interval of 30 days before planting (Adapar 2017a), and these intervals can minimize the deleterious effects on soybean. Results in the literature indicate that rainfall volumes between 33 and $95 \mathrm{~mm}$ are needed to leach dicamba for every $10 \mathrm{~cm}$ of soil profile, while this value varies from 71 to $557 \mathrm{~mm}$ for 2,4- D (Friesen 1965, Grover 1977).

There are few reports about the effects of synthetic auxin applied in preplanting, under tropical conditions, for soybean yield. Thus, field experiments should be conducted in a wide range of climatic and soil conditions to determine whether the preplant application of synthetic auxin causes yield losses in soybean. Likewise, the relevance of environmental factors in defining the safe interval for preplant application in susceptible crops, as well as the influence of normal tropical rainfall conditions, should be determined.

\section{CONCLUSION}

The application of 2,4-D to clayey Latosoil in preplant soybean does not affect the initial development of plants, regardless of the rainfall simulation. However, the rainfall accumulation of $90 \mathrm{~mm}$ before the soybean planting does not promote the dicamba dissipation, causing serious damages to the initial soybean development.

\section{REFERENCES}

AGÊNCIA DE DEFESA AGROPECUÁRIA DO PARANÁ (Adapar). ATECTRA. 2017a. Disponível em: http://www.adapar.pr.gov.br/arquivos/File/defis/DFI/ Bulas/Herbicidas/atectra160218.pdf. Acesso em: 29 maio 2019.

AGÊNCIA DE DEFESA AGROPECUÁRIA DO PARANÁ (Adapar). DMA 806 BR. 2017b. Disponível em: http://www.adapar.pr.gov.br/arquivos/File/defis/DFI/ Bulas/Herbicidas/dma806br260218.pdf. Acesso em: 29 maio 2019.
CESSNA, A. J.; KNIGHT, D.; NGOMBE, D.; WOLF, T. M. Effect of temperature on the dissipation of seven herbicides in a biobed matrix. Canadian Journal of Soil Science, v. 97, n. 4, p. 717-731, 2017.

COMFORT, S. D.; INSKEEP, W. P.; MACUR, R. E. Degradation and transport of dicamba in a clay soil. Journal of Environmental Quality, v. 21, n. 4, p. 653-658, 1992.

ENVIRONMENTAL PROTECTION AGENCY (EPA). Dicamba AG. 2017. Disponível em: https://www3. epa.gov/pesticides/chem search/ppls/083222-0001420170109.pdf. Acesso em: 29 maio 2019.

ENVIRONMENTAL PROTECTION AGENCY (EPA). Dicamba DGA. 2012. Disponível em: https://www3. epa.gov/pesticides/chem_search/ppls/083222-0003620120124.pdf. Acesso em: 29 maio 2019.

FRIESEN, H. A. The movement and persistence of dicamba in soil. Weeds, v. 13, n. 1, p. 30-33, 1965.

GROVER, R. Mobility of dicamba, picloram and 2,4-D in soil columns. Weed Science, v. 25, n. 2, p. 159-162, 1977.

INOUE, M. H.; OLIVEIRA JUNIOR, R. S.; REGITANO, J. B.; TORMENA, C. A.; TORNISIELO, V. L.; CONSTANTIN, J. Critérios para avaliação do potencial de lixiviação dos herbicidas comercializados no estado do Paraná. Planta Daninha, v. 21, n. 2, p. 313-323, 2003.

KAH, M.; BEULKE, S.; BROWN, C. D. Factors influencing degradation of pesticides in soil. Journal of Agricultural Food Chemistry, v. 55, n. 11, p. 4487-4492, 2007.

OLIVEIRA NETO, A. M.; CONSTANTIN, J.; OLIVEIRA JUNIOR, R. S.; GUERRA, N.; DAN, H. A.; VILELA, L. M. S.; BOTELHO, L. V. P.; ÁVILA, L. A. Sistemas de dessecação de manejo com atividade residual no solo para áreas de pousio de inverno infestadas com buva. Comunicata Scientiae, v. 4, n. 2, p. 120-128, 2013.

OLIVEIRA, E. P.; KUSANO, D. M.; PACHECO, A.; NARDELLI, E. M. V.; RUY, R. F.; SILVA, M. G.; TEODORO, C. A. S. Residual activity of 2,4-D amine on soybean plant development. Journal of Agronomy, v. 14, n. 4, p. 247-250, 2015.

OSIPE, J. B.; OLIVEIRA JUNIOR, R. S.; CONSTANTIN, J.; TAKANO, H. K.; BIFFE, D. F. Spectrum of weed control with 2,4-D and dicamba herbicides associated to glyphosate or not. Planta Daninha, v. 35, e017160815, 2017.

PROSTKO, K. P.; GREY, T. L.; JOHNSON, W. C.; JORDAN, D. L.; GRICHAR, W. J.; BESLER, B. A.; BREWER, K. D.; EASTIN, E. F. Influence of pre-plant applications of 2,4-D, dicamba, tribenuron, and tribenuron plus thifensulfuron on peanut. Peanut Science, v. 30, n. 1, p. 18-22, 2003. 
ROBINSON, A. P.; SIMPSON, D. M.; JOHSON, W. G. Response of glyphosate-tolerant soybean yield components to dicamba exposure. Weed Science, v. 61, n. 4, p. 526-536, 2013.

SILVA, F. M. L.; CAVALIERI, S. D.; JOSÉ, A. R. S.; ULLOA, S. M.; VELINI, E. D. Atividade residual de 2,4-D sobre a emergência de soja em solos com texturas distintas. Revista Brasileira de Herbicidas, v. 10, n. 1, p. 29-36, 2011.

SILVA, J. R. O.; MARQUES, J. N. R.; GODOY, C. V. C.; BATISTA, L. B.; SILVA, A. A.; RONCHI, C. P. 2,4-D hormesis effect on soybean. Planta Daninha, v. 37, e019216022, 2019.

SPERRY, B. P.; FERRELL, J. A.; DIAS, J. L. C. S. Sesame tolerance to preplant applications of 2,4-D and dicamba. Weed Technology, v. 31, n. 4, p. 590-598, 2017.
SPOHR, R. B.; CORCINI, A. L.; PELLEGRIN, J.; BONFANTI, J. B.; DAL SOTO, M. F.; CARDOSO, T. Desenvolvimento e validação de um simulador de chuvas portátil. Revista Brasileira de Recursos Hídricos, v. 20, n. 2, p. 411-417, 2015.

THOMPSON, M. A.; STECKEL, L. E.; ELLIS, A.; MUELLER, T. C. Soybean tolerance to early preplant applications of 2,4-D ester, 2,4-D amine, and dicamba. Weed Techonology, v. 21, n. 4, p. 882-885, 2007.

YORK, A. C.; CULPEPPER, A. S.; STEWART, A. M. Response of strip-tilled cotton to preplant applications of dicamba and 2,4-D. Journal of Cotton Science, v. 8, n. 3, p. 213-222, 2004.

ZIMMER, M.; YOUNG, B. G.; JOHNSON, W. G. Halauxifen-methyl preplant intervals and environmental conditions in soybean. Weed Technology, v. 33, n. 2, p. 680-685, 2019. 